\title{
LARGE NUMBERS IN THE OLD TESTAMENT
}

\author{
By J. W. WENHAM
}

It is notorious that the Old Testament in many places records numbers which seem impossibly large. Bishop Colenso fastened upon this point in writing The Pentateuch and Book of Joshua Critically Examined, ${ }^{1}$ and he devoted the whole of Part I to demonstrating the unhistorical character of the Pentateuch by showing the impossibility of its figures. He realized that on this ground he had an argument which would appeal to the layman, who could not be expected to follow and to weigh the intricacies of the different theories of documentary analysis. $\mathrm{He}$ appealed to common sense, and thereby marshalled what was probably the most devastating argument ever levelled against the historical character of the Old Testament. Colenso wrote his preface in 1862 , and his argument has never been satisfactorily answered.

Yet Colenso never explained how it was that these colossal figures ever came to be used. No-one in his senses would, for instance, invent the story of a bus crash in which all 16,000 passengers were killed. The more absurd the figures the less likely it is that they were invented. Absurdity suggests the likelihood that someone has been trying to transmit records faithfully, in spite of the fact that they do not seem to make sense. Failure to recognize this point has tended to make scholars cavalier in their dismissal of phenomena which are crying out for explanation.

Furthermore, Old Testament study has long been bedevilled by an unsatisfactory methodology. Critical orthodoxy at the end of the last century established a most complex system of documentary analysis, which dates much of the literature many centuries after the events it purports to record. Subsequent

1 Longmans, Green, London (1862). 
study has shown that within the putative documents there is material which must be dated far earlier than the dates originally assigned to these documents. The resulting picture of the literary history of the Old Testament is too complicated and confused to be regarded any longer as a satisfactory startingpoint for study. It seems far sounder to take each narrative as it stands, and only to invoke scribal or editorial mishandling when all other attempts to make sense of the narrative have failed. Only so will the temptation be avoided of cutting knots which with patience might be untied.

This article is divided into two parts, the first part giving in outline certain suggestions for the solution of the numerical problems; the second applies these suggestions systematically to the Old Testament narratives in the order of their occurrence. ${ }^{2}$

\section{TOWARDS A SOLUTION}

\section{(a) The state of the text}

Having been brought up on R. D. Wilson's A Scientific Investigation of the Old Testament, ${ }^{3}$ I have always believed that the Old Testament text has on the whole been marvellously preserved and that merely conjectural emendation is so precarious as to be usually of little value. Furthermore, an apparently corrupt and unintelligible text (as for instance in Hosea) will often prove to be perfectly sound and intelligible with growing knowledge. The refusal, however, even to attempt emendation in the face of some intractable difficulty can become a stupid fetish, since the existence of considerable variations between Mss and between versions provides inescapable evidence of textual change. It seems to me to be demonstrable that numbers have for various reasons been peculiarly susceptible to corruption, and that we have therefore a duty to explore the possibility of corruption in those cases where the numbers seem to be

This article is a shortened version of a paper deposited in the Tyndale House Library, Cambridge. The original paper, together with comments by members of the Tyndale Fellowship, is available for consultation in the Library. Considerations of space made it necessary to omit a discussion of longevity and of the offering of Exodus 38:24-31, a table of variants in Ezra 2 and Nehemiah 7, a note on the biblical concept of Scripture, and discussion of Judges 16:27; 2 Kings 19:35; Isaiah 37:36; Esther 9:16.

A revision of articles from the Princeton Theological Review of 1919 , published in London without date. 
inconsistent with one another or with other elements in a narrative.

In the case of the Old Testament we have, fortunately, not been left to conjecture on this matter, because there are many parallel passages in which numbers are to be found, and in some of these the numbers do not agree with one another. Seeing that there is a tendency for divergent parallel passages to become assimilated to one another, ${ }^{4}$ the likelihood of textual corruption in passages which have no parallels is at least as great as in those that have. And even in the parallel passages themselves there may have been corruption before the second of the two narratives was written.

\section{(b) Types of textual corruption}

Study of the numbers in parallel passages and in texts where there are variant readings shows the following types of textual corruption.

\section{Extra noughts can be added to a number ${ }^{5}$}

There are three noteworthy examples: 2 Samuel Io:I 8 reads '700 chariots'; I Ghronicles I9:18 reads '7,000'. I Kings 4:26 reads '40,000 stalls'; 2 Chronicles 9:25 reads '4,000'. There are variant readings for 2 Samuel 15:7, where the Syriac, Arabic, the Lucianic recension of the Lxx, and Josephus are clearly to be preferred in saying that Absalom took 4 years to work up his conspiracy, to the Hebrew, the rest of the Lxx family and Vulgate which make it 40 years. Confusion between units and tens could easily result from abbreviations which omit the feminine singular and masculine plural terminations. ${ }^{6}$

2. A digit can drop out

2 Kings 24:8: 'Jehoiachin was 18 years old when he began to reign' is probably to be preferred to 2 Chronicles $36: 9$, where he is said to have been 8 .

\footnotetext{
- This is a well-known phenomenon in the case of parallel passages in the Synoptic Gospels.

s It is of course anachronistic to speak of 'noughts' in a text which uses words rather than a numerical notation. But this is a convenient way of describing this type of variant, which (as we shall see) may itself be evidence of the use of a different notation at some stage in the transmission of the text prior to the Massoretic standardization.

- For other examples, see G. R. Driver, 'Abbreviations in the Massoretic Text', Textus I (1960) 125.
} 


\section{A numeral can drop out}

I Samuel 13:I reads 'Saul was year old'. 'Thirty years old', read by some Lxx Mss, is probably correct.

4. Sometimes the corresponding numerals seem to have no particular relation to one another

For instance, we have ' 800 ' and ' 300 ' in parallel passages ( $2 \mathrm{Sa}$. 23:8; I Gh. I I:I I); and the variant readings ' 30 ' and ' 50 ' in the LXX of Numbers 26:7.

5. Sometimes the noun to which a numeral is attached may be changed E.g. 2 Samuel I0: 18 speaks of '40,000 horsemen' and I Chronicles I9:1 8 of '40,000 footmen'; and sometimes the change is to the obvious detriment of the sense. 2 Samuel ro:6 speaks of ' 20,000 footmen' and ' 12,000 men', which becomes in I Chronicles 19:7 ' 32 ,000 chariots'. In 2 Samuel 8:4 and I Chronicles 18:4 there is some multiple corruption. The former reads ' 1,700 horsemen' and the latter ' 1,000 chariots, 7,000 horsemen'.

\section{A variant reading may suggest the insertion of a gloss into the text}

I Samuel 6:19 speaks of the smiting of '70 men, 50,000 men' at Beth-shemesh. Josephus supports three mss in omitting '50,000 men'. It has been suggested that the error arose at a time when Hebrew letters were being used for numerals and that 'ayin $(y=70)$ was mistaken for nûn $(r=50,000)$. At one stage of the history of Hebrew writing these letters were similar, and it seems possible that both readings were current and that 50,000 was a marginal gloss incorporated into the text. Though there is no direct evidence for a pre-Maccabean use of letters for numerals, G. R. Driver has demonstrated that its origin was earlier. He explains 'Saul ... reigned two years' (1 Sa. 13:I) as a misreading of $\supset$ (20) as $\beth$ (2). ${ }^{7}$

\section{A digit may be increased or decreased by one unit}

A study of the differences between the great census lists of returning captives in Ezra 2 and Nehemiah 7 is fascinating. Confining our attention only to the Hebrew text (although the LXX and Vulgate add further interesting material) we find that 23 out of the total of 142 digits show variants. In well over half

'Textus I (1960) 126f.; 4 (1964)83. 
of these cases one digit differs from the corresponding digit in the other text by one. (That is to say, for example, the digit 2 is much more likely to become I or 3 than any other number.) This (and certain other phenomena in the list) is perfectly explained by H. L. Allrick in his article in the Bulletin of the American Schools of Oriental Research, I36 (1954) 2 Iff. He refers to the fact that in ancient Aramaic documents vertical strokes are used for units and horizontal strokes for tens. The vertical digit strokes were generally grouped in threes. For the hundreds a stylized mem was used, plus vertical strokes to indicate how many hundred; for the thousands an abbreviation of the word was used, together with strokes to indicate how many thousand. 'As for the Hebrews themselves', he says (p. 24), 'there is no doubt they too employed the same principles of numerical notation.'8 It is easy to see how such a system, whether through defects of writing or of the material used or through scribal carelessness, would lead to the misreading of a number-usually making it one too big or one too small. According to Allrick something of this system is traceable back probably to the eighth century BC. Incidentally, in these lists, the names seem to show far less variation than the numbers.

This is very remarkable since the names of undistinguished persons and places are themselves peculiarly liable to corruption.

I Kings 7:26 gives the capacity of the molten sea as ' 2,000 ' baths and 2 Chronicles $4: 5$ gives it as ' 3,000 '.

\section{The sum of the individual ttems in a list does not agree with the stated total}

The total number of Levites is given in Numbers 3:39 as '22,000,' whereas the sum of the individual items is 22,300 . As the figure of ' 22,000 ' is used in the subsequent calculations of redemption money, a corruption of one of the individual items may be inferred. Perhaps Kohath (verse 28) should be 8,300 instead of ' 8,600 ', reading

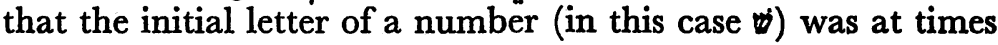
used as an abbreviation. ${ }^{9}$

Ezra 2:64 reads: 'The whole congregation was 42,36o',

${ }^{8}$ Cf. A. R. Millard, Tyndale House Bulletin I I (1962) 6-7, for evidence of Hebrew numerical signs.

Textus I (1960) 125; 4 (1964) 82f. Driver explains the 2,000 and 3,000 baths from the use of such an abbreviation. 
whereas the sum of the individual items is 29,818. (Nehemiah's list gives 31,089.) In Ezra $1: 8-1$ I the individual numbers of vessels add up to 2,499 , whereas the total is given as 5,400 . These of course may be due not to corruption, but to selective copying of a (partly illegible?) original.

We have thus a good deal of solid evidence of textual corruption in those passages to which we can apply an objective test, and therefore some indication of the kinds of corruption that are likely to exist in those passages to which we can apply no direct check.

\section{(c) The meaning of}

Most of the very large numbers with which we are concerned are in the thousands, and attempted explanations have been much occupied with the possible meanings of the root usually pointed ๆל़:

\section{Possible numerical meanings of}

In addition to $(a)$ its strict numerical meaning 'thousand', it is used (b) poetically of large numbers. When the Ark rested, Moses used to say: 'Return, O Lord, unto the ten thousands of the thousands of Israel' (Nu. 10:36, $c f$. Dt. 33:17). It is used presumably $(c)$ as a round figure-the first three large numbers in Judges are all 10,000. This may well be merely a way of saying: 'a very great number'. In any case, enemy battle casualties can seldom be intended to be anything but rough estimates. It has been suggested that large numbers are sometimes deliberately used $(d)$ hyperbolically. ${ }^{10}$

\section{Possible collective meanings of}

'ָּ is also used of a social unit: (e) 'family' (Evv, e.g. Jdg. 6:15) or $(f)$ 'clan'.11 F. Petrie suggested that it sometimes meant (g) a 'tent group' ${ }^{12}$ G. E. Mendenhall ${ }^{13}$ regards the social unit as being also $(h)$ the basic military unit of the folk army, which went to war by its

${ }^{10}$ E.g. H. L. Ellison, New Bible Commentary, I.V.F., London (1953) 340.

11 Zc. 9:7; 12:5, 6 Rsv; R. de Vaux, Ancient Israel, Darton, Longman and Todd, London (196r) 216.

12 Palestine and Israel, SPGK, London (1934) 43.

18 FBL 77 (r 958 ) $52 \mathrm{ff}$. 


\section{Possible individual meanings of}

When pointed ף' it is used of the 'chieftains' of Edom and in the modern Israeli army of the 'colonel'. Scriptio plena is not always used and the primitive text was unpointed, so that it is worth investigating whether There may at one time have been a range of such personal uses which have since become submerged in the pointed text. We certainly have it used for (i) the Edomite 'chieftain' (Gn. 36:15-43; Ex. I5:I5; I Ch. I:51-54). We probably have it (as I shall try to argue) for $(j)$ the chiliarch or captain over a thousand troops, or $(k)$ the commander of a folk 7 of indeterminate size; probably for $(l)$ the professional, fully-armed soldier; possibly for $(m)$ officers generally. ${ }^{14}$ Let us see whether the abandonment of the traditional translation of in favour of a different rendering will throw light on some of the notoriously difficult passages.

\section{(i) The attacks on Gibeah and $A$ i}

I have noticed in a number of contexts where thousands of soldiers are mentioned that they appear to be people of special distinction. In Judges 20:2: 'the chief of all the people . . . presented themselves in the assembly of the people . . 400,000 footmen that drew sword'. If these were in fact 400 s. (fullyarmed soldiers), the subsequent narrative begins to make sense. They encamp against the Benjamites in the small town of Gibeah. The Benjamite forces (verse I5) consist of 26 צִ (armed with swords) together with 700 'chosen men' armed only with slings. At the first attack (verse 21 ) the Israelites lose

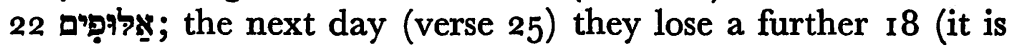
again stressed that all of the slain were armed with swords); the third day (verses 29, 34) an ambush is set, consisting of or led by

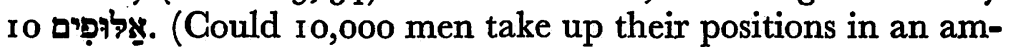
bush undetected?) The losses begin again (verse $3 \mathrm{I}$ ) 'as at other times' - the scale of which is now quite clear, for about 30

14 No use has been made of the fact in this paper, but it is worth noting that $\mathbb{X}$, the first letter of the alphabet (and the first letter of 7 ? times as a symbol both for 'one' and for 'one thousand'. As there is indirect evidence of this usage (and of the use of the first letter of a word as an abbreviation) in much earlier times, there is here a further rich field for possible confusion. 
Israelites (not apparently sword-armed a killed. The ambush then assaults the city (verse 35).25 Benjamite and a hundred others are killed. 18 of the first stage of the pursuit, 5 were later 'cut down in the high ways' and 2 more at Gidom. All 25 were 'men that drew the sword', 'men of valour'. 600 men (slingers presumably) took refuge in the rock of Rimmon for four months.

The attack on Ai has similar features. We have on the one hand the dispatch of 3,000 men, followed by the great disaster of the loss of 36 men (Jos. 7:5). Then comes the setting of the ambush (8:2ff.). 30,000 mighty men of valour set out by night on the long march up the rough track and take up their position 'not very far from the city' undetected. If we interpret this figure as 30 , we have 30 picked troops for an ambush, which seems to correspond satisfactorily with what was reckoned to be the disastrous loss of 36 men on the first assault.

\section{(ii) David's feast}

David's feast in Hebron in I Chronicles 12 appears to be attended by enormous numbers, not of ordinary men, but of distinguished leaders: 'captains of the thousands' (verse 20), 'all mighty men of valour' (verse 2I), 'captains in the host' (verse $2 \mathrm{I}$ ), 'bands that were ready armed to the war' (verse 23), 'that bare shield and spear' (verse 24). (It was not many years previously that the people had been almost without weapons. 'There was neither sword nor spear found in the hand of any of the people ... but with Saul and with Jonathan', I Samuel 13:22, $c f$. Judges 5:8.) The expression 'that bare shield and spear . . . armed to the war' in I Chronicles I 2:24 seems to be synonymous with 'mighty men of valour for the war' in verse 25. They are 'famous throughout the house of their fathers' houses' (verse 30), 'heads' (verse 32), 'such as went forth to battle, except in war with all instruments of war' (verse $33, c f$. verses

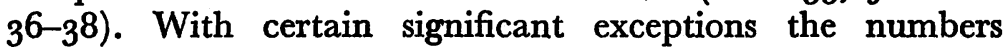
are colossal: Judah 6,800, Simeon 7, 100, Zebulun 50,000, Reuben, Gad and the half tribe of Manasseh 120,000. But in the middle of these we have Issachar, whose co-operativeness is specially mentioned, of which it is said: 'the heads of them were 200' (verses 32,40 ). In all, the men total 340,800 . 
All the individual tribal totals are given either in round thousands or in round hundreds. The immediate context seems to give the clue to what has happened. I Chronicles I2:14 says: 'These of the sons of Gad, captains of the host: he that was least was equal to (RVm RSv over) an hundred, and the greatest to (RVm RSv over) a thousand.' Then in the first verse of the next chapter it says: 'David consulted with the captains of thousands and of hundreds, and with every leader' (I3:I). It would seem that these are totals composed of a number of captains of thousands and a number of captains of hundreds. By metonymy, or by abbreviation, 'thousand' has been used for 'captain of a thousand' and 'hundred' for 'captain of a hundred'. 'Thousand' and 'hundred' have been treated as numerals and the two figures added together. When these figures are unscrambled (see pp. 44-45) we get a total of roughly 2,000 'famous men', 'heads', 'captains', which seems eminently reasonable.

\section{The size of the Israelite population}

We now turn to the most important historical question of all: the size of the Israelite population at the different stages of its history.

Much of the difficulty of this whole subject lies in the fact that we are forced to resort to a large element of conjecture and that the range of legitimate conjecture is so wide. The conjectures will carry no conviction unless the element of arbitrariness is removed by showing that the final results form a consistent picture. The first need is to try to determine what sort of population figures we are seeking.

We have two fixed points. Jacob's household in Egypt consisted of some 70 souls; the returning exiles numbered about 42,00o. These numbers are clearly meant to be regarded as literal, being itemized in detail. What happened in between?

\section{(i) At the Exodus}

The first problem to tackle is the numbers of the exodus. It is unwise to dogmatize as to the length of the sojourn in Goshen. If we are allowed the four centuries of the older chronologies, there would be nothing miraculous in an increase to two or three million in that time. If we are allowed only four or five 
generations, as many would argue on the basis of Genesis I 5: 6 and on the brevity of the contemporary genealogies, we must reckon either with an enormous birthrate or with much smaller numbers. Given a very high birthrate that quadrupled the population every generation, we should get a little over 17,500 in four generations and 70,000 in five. The truth may well lie somewhere between the two, being less than four centuries and more than four generations. Qumran has lent new importance to the Samaritan text. The Samaritan Pentateuch at Exodus I 2:40 makes the 430 years of the sojourning of the children of Israel to include Egypt and Canaan (thus agreeing with Gal. 3: 7 ). There is clear evidence from Ugaritic and early Assyrian sources that $d r$ and $d \bar{a} r u$ (cognate with the Hebrew רiv, translated 'generation' in Gn. I5:16) can refer to a period of seventy or eighty years. ${ }^{15}$ Very large numbers would easily be possible after four such 'generations'.

What general indications are there to suggest the scale of operations?

Israel 'dwelt . . . in the land of Goshen . . . and multiplied exceedingly' (Gn. 47:27), but it must be remembered that Goshen is only one area in the highly populated Nile delta, possibly to be identified with the thin irrigated strip of the Wadi Tumeilat. During the oppression they were 'scattered abroad throughout all the land of Egypt to gather stubble', but during the time of the plagues the land of Goshen was still 'where the children of Israel were' (Ex. 5:12; 9:26). 'The land was filled with them', so that the children of Israel were 'too many and too mighty' for the Egyptians, who feared a fifth column in the event of war ( $1: 7-10)$. Yet it only requires a small percentage of mistrusted foreigners in a population to cause such fears, or a small percentage of Jews to cause anti-Semitism. The people were served by two midwives ( $1: 15$ ), and it was seriously contemplated that all male babies should be thrown into the Nile. In the wilderness for most of the time, the people found sufficient to drink without the need for a miraculous supply. It was possible for the whole congregation to 'come near before the Lord', to 'look after Moses' as he went to the Tent, to hear him

${ }^{16}$ K. A. Kitchen, Ancient Orient and Old Testament, Tyndale Press, London (1966) 54. 
when he addressed them (Ex. I6:9; I9:17; 33:18; Lv. 8:3; Dt. I:I). For a time Moses attempted to adjudicate all disputes himself (Ex. 18:13). Though Moses stressed the multiplication of the people, he also declared the word of the Lord concerning the Canaanite nations: 'I will not drive them out from before thee in one year; lest the land become desolate'; and he prayed, 'The Lord . . . make you a thousand times so many more' (Ex. 23:29; Dt. I:I I). God had made them 'a nation, great, mighty, and populous,' but they were confronted with 'seven nations greater and mightier', 'the people of whom thou art afraid' (Dt. 26:5; $1: 28 ; 4: 38 ; 7: 1,19$ ). All the men of war could compass the city of Jericho seven times in one day (Jos. 6:4).

These data indicate a very large migration, tens of thousands perhaps, but not millions. In other words, the population figures as they stand in Exodus and Numbers have either been misunderstood or have become corrupted. The tribal lists in Numbers I and 26 have obviously not been invented. Various attempts have been made to explain them. One possibility is that these large numbers are not in fact single numbers, but that they each consist of two numbers which have been put together. Mendenhall's idea was that they are census lists from the period of the Judges, whose figures give first the number of צִ (which he interprets as clans) in the tribe and then the number of nisk (which he interprets as contingents) sent to war by that tribe. (Though what conceivable point there would have been in inventing two contexts in the wilderness period for these lists and in writing it all up as history passes comprehension.) Petrie's idea was that the gִ gִ gִ give the number of tent groups or families, and that the give the approximate number of fighting men in each tribe.

Both these theories break down on one simple mathematical

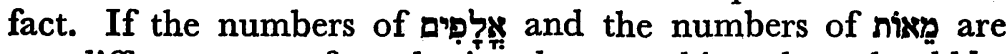
two different ways of numbering the same thing, there should be at least some correspondence between them. That is to say, on average the tribes with many should also have many תisp, and vice versa. Alas, there is no such correspondence. In Numbers I, for instance, Simeon has 59 מִאואוֹ 3 ; but Gad has less (45) (4) תising $\left(6 \frac{1}{2}\right)$ as Simeon. This lack of correspondence is general 
throughout the two lists, as R. E. D. Clark showed in his magnificent paper (to which I am greatly indebted): 'The Large Numbers of the Old Testament'.16

Clark suggested that these numerations might consist of a certain number of מלוs and a certain number of but that the number of nisp in each case exceeded ten. For instance, there might have been (not 3, but) 23 תixp in Simeon. When

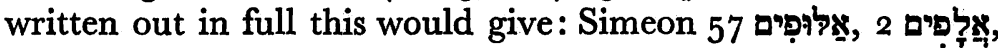
3 תix, which an uncomprehending editor could have combined

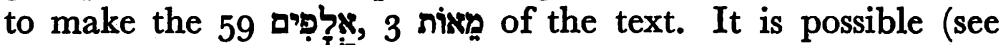
pp. 35-38) to choose figures for the șich will establish a rough correspondence between the תix.

Accepting this hypothesis for the time being, what are we to suppose the מאוא the be? Glark's view is that the איפל מאוֹ are officers and that the approximate numbers of fighting men. But when we are dealing usually with about two or three thousand men per tribe, it seems unlikely that they would only give the figure to the nearest hundred. It would make much better sense to regard the מֵָזָ as a contingent.

There are various ways of taking אלף without involving impossibly large numbers. It could be a social unit-family, clan, tent group - or such a group organized as a military unit. Or it could be an officer (as Clark maintained) or a specially trained warrior (as our study of Judges 20 suggested). There is much to be said for this last possibility. The idea that the (used in the sense of a specially trained warrior) might go right back to the time of Moses should not be dismissed out of hand. It may well be that Israelites served under Moses in the Ethiopian war of which Josephus writes in Antiquities, ii. X. It is also likely that they secretly collected weapons during the oppression. Nomads never go about unarmed and Abraham's military prowess was famous (Gn. 14). In any case it is specifically stated shortly after the Exodus that the Israelites discomfited Amalek 'with the edge of the sword' (Ex. 17:13), and the Levites were told: 'Put every man his sword by his side. (Ex. 32:27). Towards the end of the wilderness period and

10 $\mathcal{T T H T} 87$ (1955) 82ff. 
during the invasion, swords are mentioned quite frequently (Nu. 21:24; 31 :8). It is clear that the Israelite people maintained an independent community life, led by their elders (Ex. 12:21; 19:7). The Egyptians, as we have seen, regarded them as a force to be reckoned with and a potential danger to the state. Though greatly outnumbered by the Egyptians, they were a proud and able people, certainly not altogether defenceless.

Let us assume that there were such specially qualified warriors and look at the census lists again. We know that Israel at various times went to war led by captains of thousands, captains of hundreds and captains of fifties. The 24 numbers in Numbers I and 26 can be split up so that the number of per per lies somewhere between 2 and 3. This would make one ๆts available to act as 'captain of a hundred' and one as 'captain of

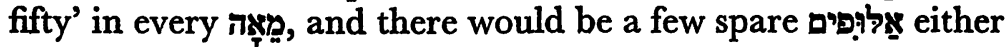
as captains of thousands or as supernumerary captains of fifties. (For details see p. 35-38)

On this reckoning we get a total of 580 sִ

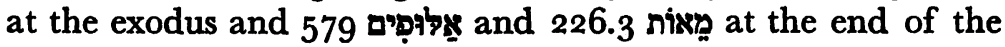
wanderings.

There are reasons for thinking (see p. 38) that the captains of thousands might normally have had 7 or 8 nisp under their command. Similarly the actual strength of an average might have been about 75 men. $235 \frac{1}{2}$ nixp of 75 men each would

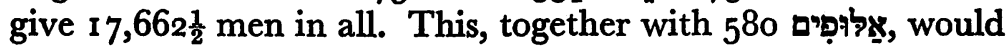
give a total fighting force of a little over 18,000 . The number of males under 20 would probably be a little smaller than the number of those over 20. But, with the addition of the Levites and of those who were too old to fight, we might expect the total number of males to be about double the number of fighting men: say, 36,000 . If we double this again, in order to include women, we shall get a figure of about 72,000 for the whole migration. (This compares with 2 or 3 million on the old reckoning, 140,000 on Clark's and 20,000 on Petrie's.) This is still a tremendous body of human beings to keep alive in that great and terrible wilderness, but it is conceivable-particularly if (as there is some reason to think) climatic conditions were slightly less arid then than they are now.

These figures were worked out from first principles simply by attempting to relate the census figures to the likely military 
organization. What was my astonishment and delight to find confirmation of the results when working independently on a quite different problem - the relation of the number of firstborn males to the number of Levites. The figure of the firstborn males of Israel is given in Numbers 3:43 the precise total of 22,273. During the austerities of the wilderness the population remained about constant and it is not unlikely that the same applied to the final part of the oppression. Let us suppose that one child out of three dies before reaching marriageable age. It would then require families of 3 children (on the average) to maintain a constant level. If families consisted of precisely 3 children, 22,273 firstborn males would represent a total male population of about $38,200^{17}$-a figure astonishingly close to the 36,000 of the earlier calculation.

\section{(ii) The number of the Levites}

The problem of the Levites for long seemed quite intractable. It seemed impossible to make sense of the figures. Numbers 3 represents the total number of Levite males as approximately equal to the total number of firstborn males of all the other twelve tribes put together-which is very odd. It says, in fact, that the total of Levite males numbered 22,000. The one figure is subtracted from the other, leaving 273 unredeemed firstborn, who are then redeemed at 5 shekels each, that is, for 1,365 shekels in all. The clue to the understanding of these figures seems to lie in the known tendency for numbers at times to acquire extra noughts (see p. $2 \mathrm{I}$ ). There are various indications that the tribe of Levi was a normal-sized tribe (see p. 39). All the Levite figures have the peculiarity of being multiples of ten. If now the final nought is removed from the total we obtain a standard-sized tribe of 2,200 males of all ages. When we do

\footnotetext{
17 The formula for proportion of firstborn males to total male population is $\frac{2^{n}-1}{2^{n-1}+n}$, where $n$ is the number of children per family. When $n=3$, the proportion is 58.3 per cent. The average number of children per family would have to be only slightly over 3 (which it might well have been) to give the exact figure of 36,000 for the total male population.
} 
our subtraction and multiplication with this new figure the following remarkable result appears:

Israelite firstborn

Male Levites

Unredeemed firstborn

Redemption money at 5 shekels each

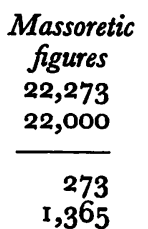

\section{Reconstructed} figures

22,273

2,200

20,073

100,365

That is to say, the two sets of figures are identical, except for the gain or loss of noughts.

\section{(iii) David's census}

This same phenomenon may also explain the difficulties in David's census. 2 Samuel 24:9 tells us that in Israel there were 800,000 that drew sword and in Judah there were 500,000 men; I Chronicles 21:5 gives the figures as 1,100,000 and 470,000. These figures are too big for the total population of military age, let alone for those who actually carried swords. R. de Vaux says rightly: 'The lower total, in 2 Samuel, is still far too high: I,300,000 men of military age would imply at least five million inhabitants, which, for Palestine, would mean nearly twice as many people to the square mile as in the most thickly populated countries of modern Europe. ${ }^{18}$ A Jewish-Israelite population of half a million would be much more convincing than one of five million, especially in view of the fact that the non-Israelite peoples, though conquered, had certainly not been absorbed. It will be noticed that the difference between the Samuel figure and the Chronicles figure is in one case 300,000 and in the other 30,000. Let us suppose that we have another example of a coalescing of two figures-one for untrained men of military age and one for professional soldiers who 'drew sword'-and let us suppose that extra noughts have been added. If we postulate original figures:

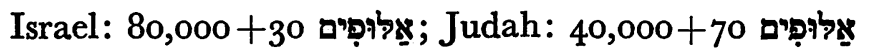
the Massoretic text of both Samuel and Chronicles can easily be accounted for.

18 Ancient Israel 65. 
GHRONICLES

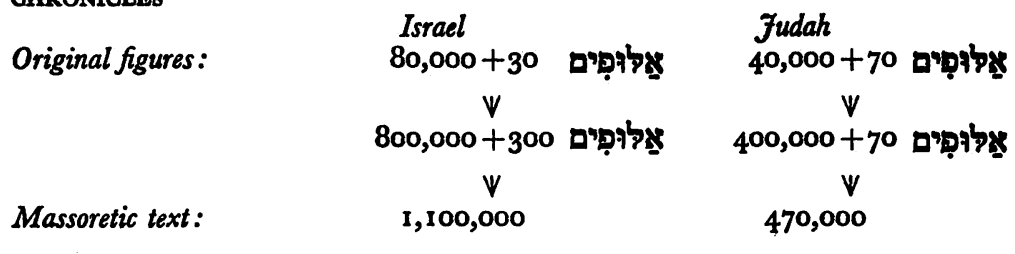

SAMUEI

Original figures:

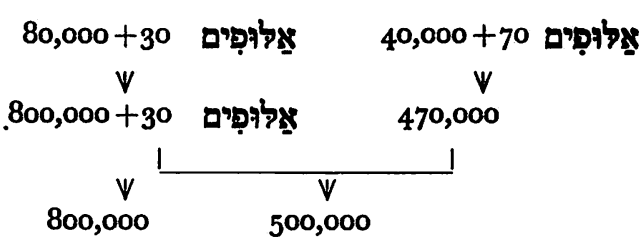

Massoretic text :

Here it would seem that the copyist, perplexed by the floating item '30 30 ' and so produced the round numbers of the Massoretic text. The lists of David's mighty men seem to lend some general confirmation of these suggested numbers of for Israel). The nucleus of his army was his 'thirty' - 'thirty and seven in all' (2 Sa. 23:8-39). Later, over ninety are named, including considerable contingents from Gad and Manasseh (I Ch. II:II-12:22).

The original figure of 100 ș age would mean a total population for Israel and Judah of nearly half a million. In the following reign Solomon numbered all the strangers that were in the land of Israel and found I 53,60o who could be set to work ( 2 Gh. 2:I 7 ). This would mean that within the boundaries of the Promised Land as originally defined, the non-Israelites would slightly outnumber the Israelites, and the overall population would be about a million.

On the lines set out above a very large proportion of the numerical difficulties can be given a satisfactory look with (usually) comparatively little textual manipulation-at best with no greater manipulation than the objective tests from the textual variants in the parallel passages entitle us to make. In the second part of this paper, the methods worked out in Part I are applied to the biblical passages seriatim. 
II. THE SUGGESTED PRINGIPLES TENTATIVELY APPLIED

It will be appreciated that there are a good many cases where a number is quite plainly too big, yet there is sufficient evidence from the context to guess even approximately what the original number might have been. In such cases a suggested figure is necessarily somewhat arbitrary.

\section{A. Exodus to Saul}

\section{Exodus 12:37: the Exodus}

'The children of Israel journeyed ... about six hundred thousand on foot that were men, beside children.' "רא translated 'thousand'

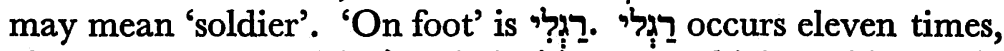

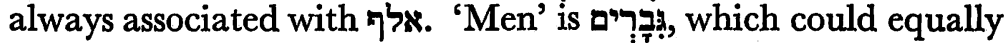

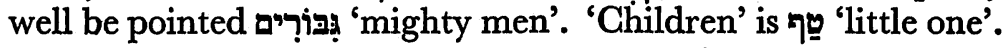
It will be noticed that no reference is made to 'women' as a separate class. In Exodus 10:9-I I Moses demanded that young and old, sons and daughters should go and serve the Lord. Pharaoh retorted that only the should go, not the others, the 'little ones'. Was it that Pharaoh would have been glad to have seen the backs of the trained men and at the same time to have retained a relatively defenceless labour force? To repoint

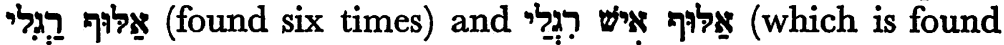
four times) and to take it as a technical term for 'trained footsoldier', nearly synonymous with רili, fits admirably with the numbers of seduced in the calculations at Numbers I (58o) and Numbers 26 (6o8). (See pp. $3^{6-38}$ for details.) The relative strength of Israel and Egypt is suggested by the

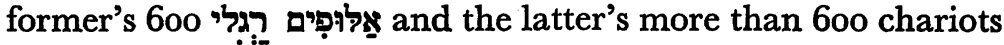
(Ex. 14:7).

\section{Exodus 32:28: the golden calf}

2,200 Levites (see p. 32) might have killed 3,000 idolatrous Israelites, but it is a huge slaughter.

\section{Numbers $I$ and 26: the two censuses}

The tribal numbers according to the Massoretic Text are: 
Reuben

Simeon

Gad

Judah

Issachar

Zebulun

Ephraim

Manasseh

Benjamin

Dan

Asher

Naphthali
Numbers $I$ Numbers 26

$46,500 \quad 43,730\left(\mathrm{Lxx}^{\mathrm{A}} 43,750\right)$

$59,300 \quad 22,200$

$45,650 \quad 40,500$

$74,600 \quad 76,500$

$54,400 \quad 64,300$

$57,400 \quad 60,500$

$40,500 \quad 32,500$ ?

32,200

35,400

62,700

41,500

53,400
52,700

$45,600(\mathrm{Lxx}, 35,500)$

64,400

$53,400(\mathrm{Lxx}, 43,400)$

45,400

The Vulgate supports the Hebrew text throughout. One or more LXX MSS differ from the Hebrew in ten out of the twentyfour numerations. The totals given in the Hebrew and the Lxx are the same. In the case of the Hebrew the totals agree with the sum of the individual items, whereas in the Lxx they do not; so it is perhaps best to assume that the Lxx numbers have been corrupted subsequently to their original translation. The catastrophic drop in the Simeon total, however, looks suspicious, and it is tempting at this point to invoke the joint aid of conjecture and the LXX, and to raise this by 30,000 to 52,200 , and to offset against it a reduction of 10,000 in three other tribes. The LXX already points to Benjamin and Asher as two of them; we might add Issachar, which otherwise shows a large increase during the wilderness period. The numbers of the 'sons of Joseph' are also suspicious. Numbers 26 reverses the order of Ephraim and Manasseh and at the same time reverses their relative sizes, making Ephraim a very small tribe. We might be justified in interchanging the figures.

If we adopt the hypothesis that these figures are made up of a number of בלפי (who are 'captains of thousands', 'captains of hundreds' and 'captains of fifties') and of a number of military units (which are called מيxis), we should expect a little over two

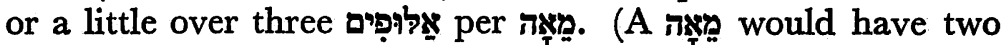
officers, if there was one 'captain of hundred' and one 'captain of fifty' per unit; or three officers, if there was one 'captain of hundred' and two 'captains of fifty'. In addition each tribe would have two or three 'captains of thousands'.) In any given tribe the number of nisp would not normally be an exact multiple of ten, so that the military. 'thousand' would consist of a 
group of תix, usually less than ten in number. (Military units seem often to be smaller than their nominal strength, but seldom larger.) If we now break up the figures on these principles, we can get a quite detailed picture of the whole military organization. The figures below marked with an asterisk incorporate the emendations suggested above. No claim is made that these (and the other conjectures involved) are more than intelligent guesses, nor that it is possible to give any great weight to the individual reconstructed figures. But it does show that the Massoretic figures could have come from the census of a carefully planned military organization.

\begin{tabular}{|c|c|c|c|c|c|c|}
\hline \multirow[b]{2}{*}{ Tribe } & \multirow{2}{*}{$\begin{array}{l}\text { Numbers } \\
\text { as given }\end{array}$} & \multicolumn{2}{|c|}{$\begin{array}{c}\begin{array}{c}\text { Numbers as } \\
\text { broken up }\end{array} \\
\end{array}$} & \multirow{2}{*}{ 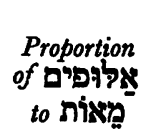 } & \multirow{2}{*}{$\begin{array}{c}\text { Number of } \\
\text { military } \\
\text { thousands }\end{array}$} & \multirow{2}{*}{$\begin{array}{l}\text { Distribution } \\
\text { of nikp in } \\
\text { thousands }\end{array}$} \\
\hline & & אַּלִּּּים & מֵאוֹת & & & \\
\hline & (1a) (rb) & $(2 a)(2 b)$ & $\left(3^{a}\right)\left(3^{b}\right)$ & $(4 a)(4 b)$ & $\left(5^{a}\right)\left(5^{b}\right)$ & (6) \\
\hline
\end{tabular}

\section{Reuben \\ $\begin{array}{cc}(\mathrm{Nu} .1) & 46,500 \\ (\mathrm{Nu} .26) & 43,730\end{array}$ \\ Simeon}

\begin{tabular}{rrc}
\multicolumn{2}{c}{ Simeon } & \\
& $(1)$ & 59,300 \\
& $(26)$ & $* 52,200$ \\
Gad & $(1)$ & 45,650 \\
& $(26)$ & 40,500
\end{tabular}

$45 \quad 42$

15

3

$\begin{array}{rrrr}57 & & 23 & \\ 44 & 50 & 165 & 22 \\ 72 & 39 & & 1 \\ & 74 & 25 & \end{array}$

Issachar

(I) 74,600

(26) $\quad 76,500$

(I) 54,400
(26)
$* 54,300$

Zebulun

$5^{2}$

(I) 57,400
(26) 60,500

Ephraim

55

(1) 40,500

$\begin{array}{ll}\text { (26) } & 40,500 \\ & 52,700\end{array}$

39

Manasseh

(1) 32,200
(26) ${ }^{*} 32,500$

Benjamin

31

(1) 35,400

$\operatorname{Lxx}(26) \quad 35,400$
${ }^{*} 35,500$

Dan (I) 62,700

Asher (1) $\quad 64,400$

LXX (26) $\quad * 43,400$

Naphthali

(1) 53,400

60

40

(26) $\quad 45,400$

5 I

Totals

$\begin{array}{ccccc}(\mathrm{Nu} .1) & 603,550 & 5^{80} & & 235.5 \\ (\mathrm{Nu} .26) & 601,630 & & 579 & 226\end{array}$

$226 \cdot 3$

30 
Notes

1. Columns ( $1 a$ ) and ( $r b$ )

The stray 30 of Reuben and 50 of Gad suggest either some small subsidiary unit or some primitive corruption. In the case of Reuben's 30 the reading of Alexandrinus (50) could be earlier.

2. Columns ( $4 a)$ and $(4 b)$

The figure in column 4 is the result of dividing the figure in column 2 by the figure in column 3 .

3. Columns ( $5 a$ ) and ( $5 b$ ) simply give the number of 'thousands' into which the תixts would have to be grouped, if the number of nixp per 'thousand' is not to exceed ro. 4. Column (6) shows how we might expect the תist to be distributed in the various 'thousands'. The result is remarkable. There would have been at one or other numbering: 2 'thousands' consisting of 6 תixts each, 16 of 7 each, 32 of 8 each and 9 of 9 each. It looks as though there was a strong preference for seven or eight nixp per 'thousand', which suggests that the size of the תik' themselves must have been somewhat elastic to make this possible. We have suggested that military units tend to be below nominal strength. If this applies to 'tens' and 'fifties', it seems reasonable to suggest 75 men as the average strength of a ixp.

That there was this tendency to aim for 'thousands' consisting of 7 or 8 תiks (and only occasionally reaching 9 or dropping to 6) may explain a very remarkable phenomenon in the original figures. Petrie observed that the hundreds digits in the tribal numbers were never $0,1,8$ or 9 . If these were straightforward census figures, there is the same likelihood of these numbers appearing as hundreds digits as there is of $2,3,4,5,6$, or 7 . Indeed the chances that these four numbers would never appear is $\left(\frac{10}{8}\right)^{24}$ to $\mathrm{I}$ against- that is, about 200,000 to 1 . To Petrie this appeared to be so unlikely to be chance that he had the idea (as we have seen) that the thousands and the hundreds were two separate sets of figures, the thousands being some sort of family group and the hundreds being the approximate number of men in the tribe-never more than 750 men, never less than 200. This is an admirable theory, apart from the awkward fact (already noted) that there is no correspondence at all between the number of family groups and the number of men. Clark's idea (which we have adopted) of breaking up the thousands overcomes this difficulty, but fails to explain why there are no tribes of $18,19,20,21$ תixp in all these numerations and why they cluster around $14-17$ and 23-25. (These numbers account for 20 of the 24 totals.) Once it is realized that there is a deliberate preference for 'thousands' composed of seven, eight, or possibly nine, 'hundreds', this phenomenon is sufficiently explained.

\section{Numbers 2: the four camps}

Re-write the summaries of the four camps thus:

verse 9 Judah (with Issachar and Zebulun): I 79 צִ 74 'hundreds' (east).

verse I6 Reuben (with Simeon and Gad): I46 $64 \frac{1}{2}$ 'hundreds' (south).

verse 24 Ephraim (with Manasseh and Benjamin): 104 4 4 I 'hundreds' (west).

verse 3 I Dan (with Asher and Naphthali): I5I 66 'hundreds' (north).

verse 32 Total: $5^{80}$ a $235 \frac{1}{2}$ 'hundreds'. 
5. Numbers 3 and 4 : the numbers of the Levites

As we have already seen (p. 32), the total of the male Levites (3:39) does not tally with the sum of the individual items. As the total 22,000 is used in the calculations of $3: 46$, we must presume that one of the individual items is too large by 300 . We have seen (p. 33) that by striking off the final nought from all the Levite numbers we reach very credible figures.

The location of the three families-Gershonites (750) west, Kohathites (860) south, Merarites (620) north-provides an interesting 'undesigned coincidence'. There are no Levites on the east where, according to Numbers $2: 9$, the largest camp was situated.

At first sight a tribe with $85^{8}$ men between the ages of 30 and $50(4: 48)$ seems absurdly large to care for the little tabernacle. It must be remembered, however, that the main task of all nomads is to keep man and beast alive, and that only a small proportion at any one time would be detailed for specifically Levitical duties. The allocation of forty-eight 'cities' to the Levites (Nu. 35:7; 21:4I) when compared with the allocations to other tribes (Jos. I3:I5-19) suggests that Levi was similar in size to the rest. 2,200 males of all ages would probably mean nearly I,200 males of military age, which would be equivalent to 16 תivin of 75 men each-a good average size for one of the smaller tribes.

\section{Numbers $I I: 2 I$}

600 foot soldiers, $c f$. Exodus $12: 37$.

\section{Numbers r6:49: plagues}

I4 צx and 700 others died of the plague? If the losses of men of military age only are included, the loss of ș would be slightly below the average of the population as a whole. If the 700 includes women and children, it would be slightly more than double the average. In either case it is a reasonable ratio. Dathan and Abiram came from Reuben. Is it coincidence that Reuben and Simeon and Gad (the two tribes in the same camp) show a drop in numbers at the second census?

\section{Numbers 25:9}

Deaths by plague: 2,400 ? 240 ? Possibly 24 צू:the wrath 
was directed against the chiefs (25:4). The named offender was a Simeonite (25:14).

9. Numbers $26: 62$

Number of Levites: $2,300, c f \cdot 3: 39$, discussed on pp. 32-33 and p. 39 .

\section{Numbers $3^{I}$ : the war against Midian}

The scale of the war would suggest 12 military 'thousands' (verses 4,5 ). That half the prey should go to those who did not fight (verse 27) is then a generous provision. The great difficulty of this passage lies in the detailed arithmetical application in verses $32-47$ of the principles set out in verses $26-30$. It is perhaps best to visualize a ruthless war of destruction during which the Israelites collected great quantities of easily carried jewelry (verse 50) and only a comparatively small number of animals $\left(6,75^{\circ}\right.$ or 675 sheep, 720 or 72 beeves, 610 or 61 asses ?) and prisoners (who were eventually reduced to 320 or 32 unmarried girls). These figures, seeming to a later editor to be altogether too small, were then made into thousands and the necessary arithmetic worked out on this basis. The object of the details is probably legal rather than historical. This detailed example shows how the law of spoils was to be applied. But the original text cannot have described the Lord's tribute as '.032 persons'!

\section{I1. Foshua 4:13: crossing the Fordan}

'About forty thousand prepared for war passed over ... to the plains of Jericho.' It is not altogether clear here whether the reference is to 40,000 armed men from Reuben, Gad and the half tribe of Manasseh, or from all Israel. In the context, the former seems the more natural. On our earlier calculations 'all Israel' had 226.3 מيאוא, which at 75 men per roughly I 7,000 men. It had 29 military 'thousands'. Neither 'seventeen thousand' or 'twenty-nine thousand' would easily become corrupted to 'forty thousand'.

On the other hand, the figures for the Transjordan tribes lead to the figure 40 quite readily. Reuben had I7.3 nisp, Gad I5 and Manasseh I5. If we halve Manasseh (as there were settlements on both sides of Jordan) the total for the two and a half 
tribes is 39.8 ממאו 40 'thousands'. Though the poetry of Deborah is no safe ground for statistics, the figure of 40,000 for the total military strength of Israel (Jdg. 5:8) would fit well at an early stage of the Judges period.

12. Joshua 8:12: $A i$

'He took about five thousand men, and set them in ambush.' We have already (p. 26) discussed the setting of an ambush of 30 צ' (in verses 3-9). The account of the ambush in verse I 2 (set in the same place) appears to be a recapitulation of what has just been recounted, but with 30,000 (which might have been written as ל) corrupted to $5,000(\pi)$.

\section{Foshua 8:25}

The total population of $\mathrm{Ai}$ would be more likely to be 1,200 than 12,000. 7:3 has already said: 'They are but few.'

\section{Fudges 7: Gideon and the Midianites}

Mendenhall gives an important place to the ๆ during the Federation. In the absence of central government between the time of Moses and the Monarchy, it seems inevitable that the tribe and the clan should be the important units. Each clan goes to war under its own commander. Gideon thinks in terms of clans: 'My family is poor in Manasseh' (6:15). It is perhaps best to regard the 32 צִ seh, Asher, Zebulun and Naphthali as 32 clans, rather than as 32,000 men, which seems too large a figure for this period. It is

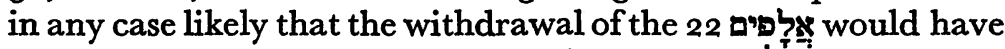
been as a result of group decisions, since we are not dealing with an individualistic age. It is from the remaining ten clans that Gideon selects the men for his three companies.

\section{Judges 8: after the Midianite defeat}

It seems that Gideon and his three hundred are now dealing with a very small remnant. It is no longer a case of surprise attack in the dark, but the attempt of a tiny band of determined men to round up the escaped Midianite leaders. Verse Io refers to ' 120 thousand men that drew sword' who had already fallen in battle; these (as in Jdg. 20:2) are evidently 120 fully armed 
warriors. The two petty kings now have only fifteen such left and they are unable to resist Gideon's final attack.

\section{Judges I2:6: Shibboleth}

In Jephthah's war against Ephraim, there fell at the fords of Jordan 42,000 who could not say 'Shibboleth'. There is no reference specifically to fighting men, though it could mean 42 צू. With the mountains skirting the Jordan valley, it is not easy to imagine very many people, either soldiers or civilians, being successfully driven into this trap. It is perhaps best to discard two or three noughts. As far as one is able to judge the scale of operations, 42 men might well have been a considerable loss.

\section{Fudges 18 and 20: the Danites}

For chapter 20 , see above, pp. 25-26. It might be noted that the incident at Gibeah is on a similar scale to that in chapter 18 , where the Danite migration is recorded. Five 'men of valour' spied out the land (verse 2) and then 600 men 'appointed with weapons of war' (verse II) undertook the assault on Laish. It seems likely that this event took place at an early stage in the Judges period, and that Samson came of one of the Danite families (13:2) which did not migrate. We have already found reason to think that the total number of men of military age in the tribe was considerably more than 600 .

18. War with Philistines, Ammonites and Amalekites: (i) I Samuel 4 'The Philistines ... slew ... a about (Lxx omits 'about') 4,00o men' (verse 2). 'There fell of Israel 30,000 footmen' (verse 10). This was in the time of Eli when the fortunes of Israel were at a very low ebb. 30,000 seems too large a number, whereas the loss of

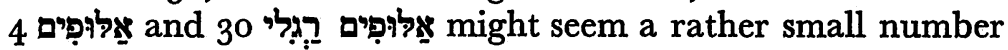
to constitute a great disaster. Yet we are approaching the period for which there is direct evidence that the initial brunt of the fighting was borne by representative figures, like David and Goliath, or the 'young men' of Abner and Joab (2 Sa. 2:14ff.), and it may well be that we have here one more example of the preoccupation of the writers of Israel's history with the professional soldier. The loss of such men at such a time could have been a disaster which paved the way for the situation in Saul's 
reign, when the people were almost entirely without sword or spear (1 Sa. 13:22).

(ii) I Samuel II

The hastily prepared relief of the town of Jabesh-gilead could have been effected by 330 (verse 8), but Saul could hardly have led 330,000 men across Jordan and into the midst of the camp in the morning watch (verse I I).

(iii) I Samuel 13:5

'The Philistines gathered themselves together to fight with Israel, 30,000 chariots and 6,000 horsemen.' The Hebrew letter $ל$ was used to represent 'thirty'. It is possible that the final ל of 'Israel' was accidentally repeated, so that $\mathrm{I}, 000$ became 30,000 .

\section{I Samuel $15: 4 f$.}

The Hebrew, as translated in the RV, reads: 'Saul... numbered them in Telaim, two hundred thousand footmen, and ten thousand men of Judah. And Saul came to the city of Amalek.' The Lxx reads: 'he numbered them in Galgala, four hundred thousand $\tau \alpha \gamma \mu \alpha \tau \omega \nu$, and Judah thirty thousand $\tau \alpha \gamma \mu \alpha \tau \omega \nu$. And Saul came to the cities of Amalek.' $\tau \alpha \gamma \mu \alpha$ suggests, perhaps, regular troops. This was one of a number of frontier campaigns (14:47f.), for which 'when Saul saw any mighty man, or any valiant man, he took him unto him' (verse 52). The Amalekites were not a large people, and this campaign did not lead to their destruction (I Sa. 27:8; 30: I-I8). It was directed mainly, if not exclusively, against one fortified village. Clearly small, highly mobile forces were needed for a raid in this arid region- a few hundred, not many thousands, of men. Therefore read: '200 foot-soldiers and ro צִ of Judah'.

\section{I Chronicles I-9: miscellaneous statistics}

In the early chapters of Chronicles a number of ancient records of varying date are collected together. These contain some quite modest figures (e.g. the 500 Simeonites who migrated to Mount Seir (4:42)), and some colossal ones (e.g. the 44,760 of the Transjordanian tribes who took from the Hagrites 50,000 camels, 250,000 sheep, 2,000 asses and 100,000 men (5:18-2I)). In chapters 7-9 there are various statistics, obviously taken from 
contemporary records, which are of peripheral interest and difficult to interpret. In these cases it is probably wisest not to attempt to guess the original numbers.

\section{B. The Parallel History: David and Solomon}

At chapter ro the first Book of Chronicles begins to run parallel with the histories of Samuel and Kings. From this point we shall consider the relevant passages concurrently in their approximate chronological order.

With the death of Saul begins the spectacular rise of David from the status of a rebel outlaw with a private army to that of monarch of a considerable empire. His army consisted first of 400 men (1 Sa. 22:2), later of 6oo (23:13; 27:2; 30:9). During the long war with Ish-bosheth, David 'waxed stronger and stronger' (2 Sa. 3:I). When Ish-bosheth was killed, all Israel gathered to David at Hebron to make him king (I Gh. I I). I Chronicles 12:24-37 enumerates the tribal leaders; it seems to represent nearly 2,000 captains of thousands and captains of hundreds. (This is argued on p. 45.) David now has a seasoned professional army, tough and highly mobile, which is supported by the tribal levies under their own leaders, and he is ready to begin the process of ejecting the Philistines and of subduing the neighbouring tribes. Inevitably the burden of aggressive fighting would fall on the central army, which could move about the country along internal lines of communication, and which could choose its own moment for a devastating raid in any direction. The tribal levies would bear the burden of local defence in the event of sudden attack.

It is reasonable to think that the number of men of military age between the time of Moses and the time of David might have risen from $I 8,000$ (see p. 3I) to I 20,000 (p. 34). 2,000 or 3,000 'captains' is a suitable number for forces of the latter size ( $c f$. 2 Sa. 6: I, discussed below).

\section{I Chronicles 12:24-37: the leaders who made David king in Hebron} Omitting the special cases of Zadok (verse 28) and Issachar (verse 32 ), the total number of 'heads' is 340,60o. (Naphtali has been taken as 38,000 .) Let us suppose that this originally represented an assembly of captains of hundreds and of captains 
of thousands, whom we might expect to be in a ratio of about 8 to I to one another. Then I captain of a thousand, together with his complement of 8 captains of hundreds ( 9 'heads' in all), will be written: $\mathrm{I}, 800$. In other words, the apparent number of 'heads' $(340,600)$ must be divided by 200 to give the true figure: 1,703. To these must be added Zadok (22) and Issachar (200), giving 1,925 .

\section{2 Samuel 6:I}

'David again gathered together all the chosen men of Israel, thirty thousand.' $C f$. I Chronicles I3: I : 'David consulted with the captains of thousands and of hundreds, even with every leader.' 'Chosen men' frequently appears to be a technical term for a military leader. If it is so in this case, the figure of nearly 2,000 in I Ghronicles 12 suggests a figure of 3,000 rather than 30,000 in this incident which follows closely upon it. The 30,000 could, however, include others who assembled along with the leaders.

3. Wars: (i) 2 Samuel $8=I$ Chronicles 18 , and 2 Samuel $10=I$ Chronicles 19

Though these accounts of the wars with Zobah, Syrians, Edomites and Ammonites are brief, they seem to represent arduous campaigns. 2 Samuel to appears to give a fuller account of what has already been recorded in 2 Samuel 8. The numbers of the losses inflicted on the enemy represent a noteworthy instance of textual variants:

2 Samuel 8:4, 5: I,700 horsemen, 20,000 footmen, 22,000 Syrians. I Chronicles 18:4, 5: 1,000 chariots, 7,000 horsemen, 20,000 footmen, 22,000 Syrians. 2 Samuel 10:18: 700 chariots, 40,000 horsemen (Syrians). I Chronicles 19:18: 7,000 chariots, 40,000 footmen (Syrians).

Of these, I Ghronicles 18:4, 5 is the fullest and most coherent, and it is fairly easy to see how the other texts could have been derived from it. These were probably David's most exacting wars, and there seems no reason to doubt that such losses were inflicted in them.

(ii) 2 Samuel $17: 1 ; 18: 7:$ the pursuit of David

To suggest the choice of 12,000 men during the night in Jeru- 
salem to chase David with his bodyguard and his six hundred veterans (I 5:18) seems excessive, as does also a death-roll of 20,000 in one day in this domestic war. The size of David's army is indicated by the fact that his commands to his lieutenants were heard by all the people (18:5). Perhaps these figures should be reduced to $I, 200$ and 2,000; possibly it is a case of 12 and 20 צֵ.

4. 2 Samuel 24:24: 50 shekels of silver $=1$ Chronicles $21: 25: 600$ shekels of gold by weight

The Syriac of Chronicles reads '50 staters', a stater being equivalent to a shekel. ' 600 shekels of gold' may be regarded as a marginal gloss which has been substituted for the original reading.

\section{I Chronicles 22:14}

'An hundred thousand talents of gold, and a thousand thousand talents of silver.' This is either deliberate and glorious hyperbole, or else several extra noughts have crept in. It may well be the former.

\section{I Chronicles 23: the numbers and duties of the Levites}

We are told that when David was old, the Levites, who had been omitted in the earlier census (21:6), were numbered. They totalled 38,000 of which 24,000 were to oversee the work of the house, 6,00o were to be officers and judges, 4,000 doorkeepers and 4,000 musicians. It is clear that we are here being given the roundest of round numbers. 24,000 seems to contemplate a division into 24 courses of $\mathrm{I}, 000$ each, along the lines explicitly laid down for the priests (chapter 24) and the musicians (25:7ff.). 6,000 and 4,000 are simple fractions of 24,000 .

The situation is that of the co-regency when Solomon had been made king, but David continued in office. Under David Israel had acquired a dominion of considerable size, which David wished to see efficiently organized on lines of strict loyalty to the law of the Lord as revealed to Moses. At the heart of it all was to be the Temple in the newly acquired central sanctuary, which was to be the focus of national unity. The precise situation is not altogether clear. It seems that David had brought the Ark into the Jebusite city and provided a tent for it and (apparently) some necessary outbuildings for those who attended to it (15:1; 
I6: I), but the tabernacle and the altar of burnt offerings were at Gibeon (2 1:29). There was some division of functions between Jerusalem and Gibeon (1 Ch. 16:1-6; 2 Ch. $1: 3-6$ ). It is very doubtful whether David intended every Levite to take his turn of duty in Jerusalem during this period. It was probably a provisional plan, prepared for the day when the Temple was in operation. David regarded his plan as a 'pattern ... that he had by the spirit ... from the hand of the Lord' (I Ch. 28:I I-I9). These figures, 24,000, 6,000, 4,000, evidently lay down the proportion of the various Levitical functions. They do not represent an actual count of those at work. I Chronicles gives two such counts. The date of the first (9:14-29) is a matter of dispute. It gives the number of gatekeepers who lived in and around Jerusalem, who were 'to come in every seven days from time to time', as 212. (Contrast the 4,000 of 23:5.) The second (15:I-10) recounts how 'David assembled all Israel at Jerusalem, to bring up the ark' and lists 862 Levites. (Contrast the 38,000 of 23:3.)

Israel was now united as never before since the time of Moses, and David's plan was to put the full Mosaic system into operation. The local sanctuaries would become redundant, and if all priests and all Levites were to have an opportunity of serving the Lord in Jerusalem, it must be on a rota system. It would seem that he envisaged the current arrangements in Jerusalem being extended to priests and Levites throughout the country. The notion of 24 courses must have been based on a realistic assessment of the number of men involved. 38,000 (the figure which now stands in the text) would mean 24 courses of roughly 1,600 each. Even allowing for the possibility that there might have been more Levites than the work merited, it would be intolerable to have 1,600 temple servants in so small an area. 160 , on the other hand, would be a very reasonable figure. We suggest, therefore, that all the figures of 23:3-5 should be divided by ten, as they were in Numbers 3 . The 3,800 Levites who were numbered were aged 30 to 50 . Had those between 20 and 30 also been numbered the figure would have been rather less than 6,000 . This tallies fairly well with the figure of 80,000 , which we calculated to be the total number of men of military age of the ten tribes of Israel which Joab numbered (see p. 33). When Judah is left out of account, the tribe of Levi is then rather less 
than three-quarters the size of the average Israelite tribe, which is still probably a good average size for one of the smaller tribes.

\section{I Chronicles 27: David's monthly courses}

It is by no means clear what these twelve courses of 24,000 each are, but it would appear to be another of David's blue-prints for the future, based on the census. The neatness of the figures suggests an ideal pattern rather than an actual organization. Our reconstruction of the census indicated a total of 120,000 men of military age in Israel and Judah together with I 00 ax. If the passage under consideration is speaking of the grouping of these men into twelve divisions, we should expect 10,000 men per division, rather than 24,000. But if a military 'thousand' is (as we have had reason to suspect, p. $3^{8}$ ) considerably less than I,000 men, these figures are not incompatible. If a 'thousand' consisted of roughly 7 תixp of 60 men each, I0,000 men would make up 24 'thousands'. (For the wilderness censuses we postulated 7 or 8 תixp of 75 men each. Both figures are perfectly possible, and there is no reason why the practice at such widely different periods should be precisely the same. A ș of sixty men might have 7 or 8 'tens' of about 8 men each.)

However, it is not easy to give concrete form to the concept of a monthly 'course' of 24 'thousands'. Are they men of military age who are 'on call' for a month at a time? If so, they certainly would not have been billeted in the little town of Jerusalem. If they were on call in their homes, they would have no sense of coherence unless the 'courses' were topographically compact. No mention is made of the complex organization which such an arrangement would require. In any case it would be curious, in the unsettled state of the surrounding countries, to have one course on duty in Transjordan one month, then another in the north the next, then another in the south in the following month. Could it be that we have here a rota of 24 as per month, who 'came in and went out' of Ferusalem, chosen from 'the captains of thousands and of hundreds, and their officers' (verse I)? This would be a means whereby the king could keep in touch with his military leaders. The total number of 288 צू would presumably consist partly of the 100 who were 
attached to the tribal militia and partly of the warriors serving in the king's army.

\section{I Chronicles 29:4, 7: Offerings for the temple}

David gives 3,000 talents and the princes give 5,000 talents of gold for the house of God. Since a talent is about 66 pounds weight, we have here more than half a million pounds weight of gold alone. In spite of the fact that enormous quantities of gold and silver booty are mentioned with apparent sobriety in ancient times, it would seem that one, two or even three noughts ought to be taken from these figures.

\section{Overseers}

I Kings 5:16: 3,300 over the work; 2 Chronicles 2:18: 3,600 overseers. I Kings 9:23: 550 over Solomon's work; 2 Chronicles 8:10: 250 over the people. It would seem probable that one group of 300 men has been reckoned with one category in Kings and with another in Chronicles.

\section{Sacrificial Offerings}

I Kings 8:63; 2 Chronicles 7:5. At the consecration of the Temple Solomon is said to have sacrificed 22,000 oxen and I20,000 sheep. This would require nearly 20 sacrifices a minute for ten hours a day for twelve days. We know that most efficient arrangements were made in New Testament times to cope with the vast crowds (which included many from the Diaspora) who came to offer sacrifice at the festivals. But for such proportion of the population of half a million as might be able to assemble for this occasion in Jerusalem, figures of 2,200 and 12,000 seem more reasonable. At Hezekiah's hastily prepared re-consecration of the Temple, there was difficulty in dealing with 3,970 offerings (2 Ch. 29:32-36). At the great Passover later in his reign, Hezekiah provides 19,000 animals (30:24). In Josiah's time, $4^{\mathrm{I}}, 400$ animals were said to have been offered in one day (35:7-9). One suspects that the figure for Josiah's reign is too big, and quite possibly also that of Hezekiah's reign.

\section{The Divided Monarchy}

In the latter years of the reign of David and in the days of Solomon, the nation reached its zenith. But after the disruption, 
Israel and Judah became two petty kingdoms-a fact which is usually heavily disguised by the military figures. Occasionally, however, the disguise is removed and the truth emerges plainly.

1. Ahab was one of the more noteworthy of the northern kings. Ben-hadad, king of Syria, accompanied by thirty-two 'kings', mounted a major campaign against him. Supported by chariotry he besieged Samaria, Ahab's capital city. The Israelites were heavily outnumbered and in dire straits. Ahab then assembled his forces to attempt a break-out. He mustered first 'the young men of the princes of the provinces', 232 in number

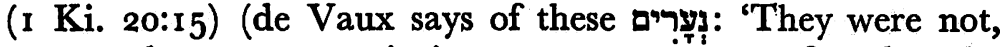
apparently, young recruits in contrast to veterans, for when the term is to be taken in a strictly military sense, it means simply professional soldiers. . . . The word had a military sense in Canaanite. ${ }^{19}$ ) 'After these he mustered all the people ... being seven thousand.' They surprised the Syrians while drinking, and routed them.

This incident is very instructive for two reasons. First, it shows the scale of an important engagement. Secondly, it shows the system in operation of a small professional force, backed by a much larger people's army. If we are allowed to give אל א all the remaining numerical problems of the parallel history fall into place.

In Ahab's second round with Ben-hadad, the Israelite camp was said to be very small compared with that of the Syrians'like two little flocks of kids' ( I Ki. 20:27). In the ensuing battle the Israelites slew 100 professional foot-soldiers in one day and the city wall of Aphek fell on a further 27.

2. After the disruption, Rehoboam was able (not surprisingly) to boast a standing army of only 180 'chosen men', 'warriors' with which to fight Israel (I Ki. I2:2 I; 2 Ch. I I:I). Abijah had 400 'chosen men', 'valiant men of war', to oppose to Jeroboam's 800 'mighty men of valour' (2 Ch. I 3:3). Abijah slew them with a great slaughter, killing 500 'chosen men' (verses i 7 f.). Asa's army 'that bare bucklers and spears', 'all ... mighty men of

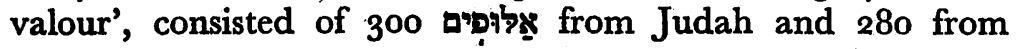

19 Ancient Israel, 221. 
Benjamin, which routed I,000 Ethiopians (14:8-13). Jehoshaphat 'waxed great exceedingly . . . he had . . . men of war, mighty men of valour, in Jerusalem ... of Judah, the captains of thousands; Adnah the captain, and with him mighty men of valour $300 \ldots 280 \ldots 200 \ldots 200 \ldots 180 \ldots$ These waited on the king, beside those whom the king put in the fenced cities throughout all Judah' (2 Ch. I 7:12-19).

3. Amaziah had 300 'chosen men', 'that could handle spear and shield'. He hired a further 100 'mighty men of valour out of Israel for an hundred talents of silver.' In the engagement with Edom they smote (RV) 'ro,000. And other I0,000 (they brought) ... unto the top of the rock, and cast them down ... that they all were broken in pieces' ( 2 Ch. 25: 5-12). In a war on this scale to have destroyed twenty of the enemy's best troops would have been a satisfactory result. The solemn precipitation of 10,000 men to their death at the foot of a cliff is scarcely conceivable. On the other hand, the dismissed mercenaries, going berserk while the army was fighting Edom, might well have killed literally 3,000 civilians in their lust for war and spoil (verse 13).

4. Under Pekah, Israel slew 120 valiant men in Judah in one day, and then proceeded to take women and children as captives to Samaria. Chided by the prophet Oded, the Israelites fed their captives and where necessary provided them with clothes and transport and sent them back south. Their number might have been 200 or 2,000, but not 200,000 (2 Ch. 28:6-15).

5. The forces of Uzziah consisted of 2,600 'heads' with 307,500 under them (2 Ch. 26: I I-I 4). This passage probably requires a different explanation. Uzziah's reign was one of great military success (verses 6-9, I5). It would seem that verse 13 refers to supplementary forces that were raised 'to help the king against the enemy', over and above the professional army. It would be reasonable to envisage the tribal militia, led by 2,600 'heads of father's houses' and (other?) 'mighty men of valour', organized as a conscript army which could be called upon 'by bands' as necessity required. The population of military age in Judah in David's day (according to our previous calculations) was 40,000. If 307,500 were emended to 37,500 we should have a very satisfactory figure for the Judah of this date. Such a 
figure also tallies well with the number of 'men of might' deported after Nebuchadnezzar's first attack upon Jerusalem, which is given as 7,000 (2 Ki. 24:16). The defeat was severe, but not so disastrous as to prevent a rebellion by Zedekiah, which led to a further, and more devastating, sacking of Jerusalem ( $2 \mathrm{Ki}$.

24: 20-25:2 I).

III. CONGLUSION

We have now examined the majority of the noteworthy instances of very large numbers. The conclusions which we have reached of course lay no claim to detailed accuracy. There is too much conjecture and too many chains of reasoning lying behind many of the suggested solutions to the problems to allow great solidity of assurance as to the correctness of the details. Yet overall there emerges a general framework of remarkable consistency, which has the appearance of a genuine correspondence with the historical picture which the other data present. Jacob's family of seventy souls grows to a host of some 70,000 in Egypt. At the height of its prosperity the nation numbers half a million, but then breaks up into two petty kingdoms, which eventually suffer crippling deportations. Judah receives back some tens of thousands of exiles with which to attempt a rebuilding of the nation.

The one element in the solution to which it is difficult to adjust the mind is the prominent part played by the iss. Suddenly to substitute quite small numbers of professional soldiers in the place of numbers a thousand times bigger is drastic treatment. It does not seem to be the 'natural' way to read these passages, and it is passing strange that the LXX translators and the Massoretes misunderstood them. The explanation must surely lie in the effects of two generations of complete disarmament during the Captivity, when the as a military figure became completely unknown. That the records should so often only mention the numbers of and ignore the tribal militia is not on reflection strange. In warfare certain troops and certain armaments have an importance out of all proportion to others. The loss of a knight-atarms was more significant than the loss of several bowmen. The 
loss of a gun or a tank or a Spitfire meant more than the loss of many soldiers. The central government in Judah, without despising the help of the tribal contingents, would count its real strength in terms of its fully trained, fully armed, professional soldiers. To lose a score of such men was no light matter.

When this mental adjustment has been made many passages appear in quite a new light. The absurd suddenly becomes vividly real; fantasy becomes history. Paradoxically (as we observed earlier) absurdity and unintelligibility are often signs of genuineness. That a passage which is apparently absurd or unintelligible has been so transmitted for century after century is a testimony to the scribes' attempted faithfulness to their sacred texts. Nowhere have we greater assurance that the author is transcribing written records than in the obscurities of the early chapters of Chronicles. There is little doubt that once the key has been found that offers a broad, general understanding of the behaviour of numbers in biblical texts, progress can be made in the understanding of individual passages.

The present study offers tentative solutions to a number of problems, but it also raises a host of further questions which are worthy of detailed research. In due course, better solutions will doubtless be found to some of the problems. In the meantime we may hope for one useful result. We may hope that the temptation cavalierly to dismiss a passage which seems obviously unhistorical will be replaced by the conviction that the passage must originally have made sense, and will endue the scholar with patience in trying to recapture its meaning. Colenso, for all his brilliance and all his earnestness, taught his readers not to take seriously great tracts of Old Testament history. In doing so he taught impatience, and so set up a barrier to discovery. In the way of patience lies progress.

(C) $1967 \mathrm{~J}$. W. WENhaM 